Ann. Biol. anim. Bioch. Biophys., 1978, 18 (4), 1073-1076.

\title{
Cryopreservation of the sperm of some freshwater teleosts
}

\author{
par H. STEIN, H. BAYRLE
}

\author{
Department of Zoology, Parasitology and Fishbiology, \\ Technical University of Munich/Weihenstephan, \\ 8050 Freising, West Germany.
}

Summary. The sperm of 7 freshwater fishes was cryopreserved using the pellet technique of Nagase (1964). The fertilization rate in the rainbow trout was about 80 p. 100 when the sperm was equilibrated for $15 \mathrm{mins}$ before deep freezing. Under the same conditions, the fertilization rate in the brown trout was about 70 p. 100 . All the other species included in the experiments also showed high activity of frozen and thawed spermatozoa, but the fertilization rate was low or zero. It was more difficult to cryopreserve the sperm of cyprinid fishes than the sperm of salmonid fishes, although the activity of the thawed spermatozoa was the same. There are few papers describing experiments and fertilization rates with cryopreserved cyprinid sperm, and further experimentation is thus necessary.

\section{Introduction.}

Some of the genetic progress in the breeding of domestic animals can only be obtained by applying the technique of sperm-cryopreservation. This technique would also open the way to new opportunities in the prodagation of cultivated freshwater fishes if their sperm could be preserved.

The present investigations were aimed at developing a technique for deep freezing the sperm of freshwater fishes living under the climatic conditions of West Germany.

\section{Materials and methods.}

The subjects under investigation during the breeding season of $1976 / 77$ were the rainbow trout (Salmo gairdneri Richardson), the brown trout (Salmo trutta forma fario L.), the brook trout (Salvelinus fontinalis Mitchill), the danube salmon (Hucho hucho L.), the grayling (Thymallus thymallus L.), the pike (Esox lucius L.) and the carp (Cyprinus carpio L.).

The sperm was taken by hand stripping from the males and collected in syringes. In the period between collection and cryopreservation the syringes were stored in pond water in order to maintain a constant temperature.

One drop of the sample of each male was examined microscopically before and after dilution with water and dilution medium. Only samples without activity before 
dilution and high activity after dilution with water were used for cryopreservation experiments.

The sperm was cryopreserved according to the technique described by Nagase (1964). After dilution the sperm was dropped on carbon ice and stored in liquid nitrogen. The extender always contained 10 p. 100 DMSO. The dilution ratio was $1: 3$ and the size of the pellets $0.2 \mathrm{ml}$. For thawing, 3 of the pellets were put in $10 \mathrm{ml}$ of a $1 \mathrm{p} .100$ $\mathrm{NaHCO}_{3}$ solution. The thawing process was accelerated by rapid shaking. Immediately after thawing the pellets were poured over the eggs or examined microscopically. The sperm was thawed after a storage period of 7 days. According to the results of earlier experiments (Stein, 1976 ; Stein and Lamina, 1976) we tested two different extenders without equilibration time and with an equilibration time of 15 and $20 \mathrm{~min}$. because we found that the equilibration time differs depending on the extender and the species.

Extender 1 : $750 \mathrm{mg} \mathrm{NaCl}, 200 \mathrm{mg} \mathrm{NaHCO}, 53 \mathrm{mg} \mathrm{Na}{ }_{2} \mathrm{HPO}_{4}, 23 \mathrm{mg} \mathrm{MgSO}$. $7 \mathrm{H}_{2} \mathrm{O}$, $38 \mathrm{mg} \mathrm{KCl}, 46 \mathrm{mg} \mathrm{CaCl} 2.2 \mathrm{H}_{2} \mathrm{O}, 100 \mathrm{mg}$ glucose, $500 \mathrm{mg}$ glycine, $100 \mathrm{ml} \mathrm{H} \mathrm{H}_{2} \mathrm{O}$, $20 \mathrm{ml}$ egg yolk $(=\mathrm{V} 2)$.

Extender 2 : $750 \mathrm{mg} \mathrm{NaCl}, 200 \mathrm{mg} \mathrm{NaHCO}, 38 \mathrm{mg} \mathrm{KCl}, 100 \mathrm{mg}$ glucose, $100 \mathrm{ml} \mathrm{H}_{2} \mathrm{O}$, $20 \mathrm{ml}$ egg yolk (= V2e $)$.

TABLE 1

Results of fertilization experiments of the breeding season 1976/77

\begin{tabular}{|c|c|c|c|c|c|c|c|}
\hline \multirow{2}{*}{ Species } & \multirow{2}{*}{$\begin{array}{l}\text { Dilution } \\
\text { medium }\end{array}$} & \multirow{2}{*}{$\begin{array}{l}\text { Equil. } \\
\text { time }\end{array}$} & \multirow{2}{*}{$n$} & \multirow{2}{*}{$\begin{array}{l}\text { Fertil. } \\
\text { rate } \\
\pm \mathrm{SD}^{*}\end{array}$} & \multirow{2}{*}{$\begin{array}{l}\text { Number of } \\
\text { eggs/sample }\end{array}$} & \multicolumn{2}{|c|}{ Spermatozoa/egg } \\
\hline & & & & & & frozen & fresh \\
\hline \multirow[t]{3}{*}{ Rainbow trout } & $\mathrm{V} 2$ & 0 & 15 & $\begin{array}{r}78,1 \\
+6,9\end{array}$ & 500 & $4-6.10^{6}$ & \\
\hline & $\mathrm{V} 2 \mathrm{e}$ & 15 & 26 & $\begin{array}{r}+81,9 \\
+3,8\end{array}$ & - & - & \\
\hline & control & & 30 & $\begin{array}{r}87,9 \\
+17,3\end{array}$ & - & & $6-10.10^{\circ}$ \\
\hline \multirow[t]{3}{*}{ Brown trout } & V2 & 0 & 15 & $\begin{array}{r}41,2 \\
+176\end{array}$ & - & - & \\
\hline & $\mathrm{V} 2 \mathrm{e}$ & 15 & 5 & $\begin{array}{r}77,0 \\
\pm 6,5\end{array}$ & - & - & \\
\hline & control & & 20 & $\begin{array}{r}90,2 \\
+\quad 93\end{array}$ & - & - & \\
\hline \multirow[t]{3}{*}{ Grayling } & $\mathrm{V} 2$ & 0 & 6 & $\begin{array}{r}46,8 \\
+19,0\end{array}$ & 1500 & $1-2.10^{6}$ & \\
\hline & $v_{2}$ & 20 & 9 & $\begin{array}{r}55,0 \\
\pm 15,4\end{array}$ & - & - & \\
\hline & control & & 6 & $\begin{array}{r}95,3 \\
+\quad 2,4\end{array}$ & - & & $2-3.10^{6}$ \\
\hline Brook trout & $\mathrm{V} 2$ & 0 & 4 & $\begin{array}{r}27,4 \\
\pm \quad 7,3\end{array}$ & 500 & $4-6.10^{8}$ & \\
\hline Danube salmon & $V_{2}$ & 0 & 2 & $\begin{array}{r}22,5 \\
+1,6\end{array}$ & 500 & $4-6.10^{8}$ & \\
\hline Pike & V2 (650) & 0 & 2 & $\begin{array}{r}25,0 \\
+2,4\end{array}$ & 5000 & $0,8 \cdot 10^{6}$ & \\
\hline Carp & $\begin{array}{l}\text { V2 } \\
\text { control }\end{array}$ & 0 & $\begin{array}{l}2 \\
1\end{array}$ & 81,0 & $\begin{array}{c}20000 \\
-\end{array}$ & $0,4.10^{6}$ & $1.10^{6}$ \\
\hline
\end{tabular}

* SD : standard deviation. 
In the pike the $\mathrm{NaCl}$ content of Extender 1 was reduced to $650 \mathrm{mg} / 100 \mathrm{ml}$ because there was a better motility.

The F-test was used to test the significance between different treatments.

\section{Results.}

The most interesting results of the fertilization experiments of the breeding season 1976/77 are summarized in table 1.

There was alway high motility in the dilution medium before and after freezing. More than 70 p. 100 of the spermatozoa were motile. The duration of the motility of the thawed spermatozoa was about $30 \mathrm{~s}$. In the rainbow trout the difference in the fertilization rate between $V 2$ and $V 2 e$ with equilibration is statistically significant; in the brown trout the difference is highly significant. The difference between equilibrated and nonequilibrated sperm in the grayling is not significant.

There was high motility in the thawed sperm of the carp too, but no fertilizing capacity.

In the brook trout, danube salmon and pike we could not obtain fresh eggs and fresh sperm at the same time, so control tests were impossible.

\section{Discussion.}

In the rainbow trout and brown trout the fertilization rate was improved by applying a new extender and an equilibration time of 15 minutes. As compared to our earlier experiments it is now possible to cryopreserve the sperm of the rainbow trout with a fertilization rate of 80 p. 100 and with small variance. In the brown trout the new technique succeeded with a significantly higher fertilization rate but there is still a difference between the two trout species. This difference is very marked in $\mathrm{V} 2$ without equilibration time. The number of experiments with the sperm of the brook trout, the danube salmon and the pike was low because we had no more males and females. But the experiments corroborated our earlier results showing that it is possible to cryopreserve the sperm of these species with a relatively low fertilization rate. Further improvement is certainly possible but it is difficult to procure the material.

We could not do more experiments on the grayling either to demonstrate a possible significant increase of the fertilization rate with equilibrated sperm. In the thawed semen of the carp there was high motility, but no fertilizing capacity. The eggs were possibly affected by the thawing solution or the extender. It seems to be very difficult to cryopreserve the sperm of cyprinid fishes. Thus, there are only two papers describing successful fertilization tests with cryopreserved sperm in cyprinid fishes (Moczarski, 1976, 1977).

\section{Conclusion.}

The experiments point out that the sperm of salmonid and esocid fishes can be cryopreserved using the technique of Nagase (1964). In the rainbow trout a practical application of this technique would bring a relatively small loss of fertilizing capacity. 
Acknowledgements. - This work was sponsored in part by the Bavarian Ministry of Agriculture. It is a part of $\mathrm{H}$. Bayrle's dissertation.

Résumé. La congélation du sperme de 7 téléostéens d'eau douce a été expérimentée en utilisant la technique de Nagase (1964). Avec $15 \mathrm{mn}$ d'équilibration, les taux moyens de fécondation obtenus après décongélation ont été de 80 p. 100 chez Salmo gairdneri et environ 70 p. 100 chez Salmo trutto forma fario. Le sperme des autres espèces s'est révélé motile, mais peu fécondant, après décongélation. La conservation du pouvoir fécondant du sperme après congélation semble plus difficile à obtenir chez les Cyprinidés que chez les Salmonidés

\section{References}

MOCZARSKI M., 1977. Deep freezing of carp (Cyprinus carpio L.) sperm. Bull. Acad. pol. Sci. (in print) MOCZARSKI M., 1976. Cryobiological factors in grass carp sperm preservation 8 th int. Congr. anim. Reprod. artif. Insem. Cracov.

NAGASE H., 1964. Deep freezing bull semen in concentrated pellet form. Proc. int. Congr. Reprod. anim. Insem. artif., Trento 3, 503.

STEIN H., 1976. Zur Gefrierkonservierung von Fischsperma. Tierzüchter, 28, 498.

STEIN H., LAMINA J., 1976. Beobachtungen zum Befruchtungsergebnis mit tiefgefrorenem Forellensperma. Berl. Münch. tierärztl. Wschr., 89, 344. 